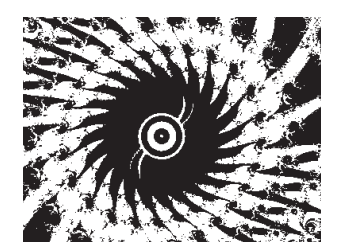

doi:10.5559/di.21.2.07

\title{
RAZLIKE MEĐU MLADIĆIMA S RANIM I KASNIM JAVLJANJEM DRUŠTVENO NEPRIHVATLJIVA PONAŠANJA
}

Daniela ŠINCEK

Filozofski fakultet, Osijek

Marina AJDUKOVIĆ

Pravni fakultet, Zagreb

UDK: 316.624.3-053.6-055.1(497.5)

Izvorni znanstveni rad

Primljeno: 2. 2. 2011.

Taksonomije društveno neprihvatlijiva ponašanja razlikuju mlade s kasnim i ranim javljanjem društveno neprihvatljiva ponašanja. Mladi kod kojih se ova ponašanja ranije javljaju smatraju se rizičnijima. Istraživanja su pokazala da ranom javljanju više pridonose ponašanja roditelia, a ustrajavanju u tom ponašanju više pridonose vršnjaci. Cilj ovog istraživanja bio je provjeriti razlikuju li se mladi s ranim i kasnim javljanjem po intenzitetu svog društveno neprihvatljiva ponašanja te po izraženosti nekih činitelja rizika (sociodemografska obiliežja, problemi ponašanja i doživljavanja, roditelisko ponašanje i obiliežja vršnjačke skupine). Istraživanje je provedeno sa 661 mladićem, učenicima završnih razreda srednijh škola u Osijeku i Zagrebu. Podijelieni su u tri skupine: mladi s niskom razinom društveno neprihvatljiva ponašanja ( $N=227)$, mladi s kasnim javljanjem društveno neprihvatljiva ponašanja $(\mathrm{N}=231)$ i mladi s ranim javljanjem društveno neprihvatliiva ponašanja ( $N=203$ ). Rezultati pokazuju da mladi s ranim javljanjem društveno neprihvatlijva ponašanja očituju izraženije takvo ponašanje u odnosu na mlade $s$ kasnim jarlianjem društveno neprihvatliiva ponašanja. Razlikuju se i po osobinama vršnjačke skupine, pri čemu mladi s ranim javljanjem društveno neprihvatlijva ponašanja percipiraju svoje vršnjake rizičnijima i doživlijavaju veći vršnjački utjecaj. Drugi činitelii rizika u ove dvije skupine podjednako su izraženi.

Ključne riječi: društveno neprihvatljivo ponašanje, adolescenti, rano i kasno javljanje

Daniela Šincek, Sveučilište J. J. Strossmayera, Filozofski fakultet, Studii psihologije, L. Jägera 9, 31000 Osiijek, Hrvatska.

E-mail: daniela.sincek@gmail.com 
Jedno od najvažnijih prediktora izraženosti društveno neprihvatljiva ponašanja mladih, uključujući vršenje kaznenih djela, jest dob u kojoj se prvi put javljaju njihova rizična ponašanja (Rutter i sur., 1998.). Polazeći od toga, nastale su poznate i danas općeprihvaćene taksonomije (npr. Patterson i sur., 1992.; Moffitt, 1993.; Loeber i Stouthamer-Loeber, 1986.; Thornberry, 1987.; Farrington, 2003.). Moffitt (1990., 1993.) razlikuje cjeloživotno društveno neprihvatljivo ponašanje i ono koje je ograničeno na adolescenciju. Prema njezinim postavkama, cjeloživotno društveno neprihvatljivo ponašanje počinje ranije i uzrokovano je rano nastalim neuropsihološkim ograničenjima u interakciji s nepovoljnim obilježjima roditelja. Društveno neprihvatljivo ponašanje ograničeno na adolescenciju pripisuje se socijalnoj mimikriji, odnosno oponašanju društveno neprihvatljiva ponašanja mladih, koji su s njim počeli još u djetinjstvu i tako ostvarili neke ciljeve (npr. ranije konzumiranje alkohola može pridonijeti statusu u vršnjačkoj skupini ili omogućiti "ulazak" u društvo starijih). Odrastanjem nestaje taj motiv i ovi mladi prestaju s takvim ponašanjem.

Moffitt i sur. (2001.) pokazuju da do 18. godine 91\% mladića i $86 \%$ djevojaka u njihovu uzorku samoiskazuje neki oblik ozbiljnijega društveno neprihvatljiva ponašanja, što ide u prilog njihovim pretpostavkama o tome da je društveno neprihvatljivo ponašanje $u$ adolescenciji normativno ponašanje.

I Patterson i suradnici razvili su taksonomiju u kojoj razlikuju rano i kasno javljanje društveno neprihvatljiva ponašanja te proveli brojna istraživanja proučavajući činitelje rizika povezane s obilježjima dječaka/mladića, obitelji i njihovih vršnjaka (npr. Patterson, 1998., 2004.; Patterson i Stouthamer-Loeber, 1984.; Patterson i Yoerger, 2004.; Patterson i sur., 1992., 2004., 2005.; Dishion i Owen, 2002.; Dishion i Patterson, 1999., 2006.; Dishion i sur., 1992., 1997., 1999.a, 1999.b, 2001.; Reid i sur., 2004.; Snyder, 2004.; Snyder i Patterson, 1987.; Snyder i Stoolmiller, 2004.). Za pojavu društveno neprihvatljiva ponašanja važne su osobine dječaka i njegovih roditelja, ali i njihova interakcija. Osobito je važan tzv. mehanizam prisile, koji nehotice potkrep-

TTermini otvorena i prikrivena ponašanja odnose se na razlikovanje ponašanja na temeliu toga koliko su vidliiva roditeliima. Roditelii lako vide da im se dieca suprotstavljaju, dok se npr. krađe $u$ društvu vršnjaka obično odvijaju u razdobljima kad roditelii ne nadziru dijete/adolescenta. ljuje agresivno ponašanje djece. Odrastanjem, problemi se očituju u sve više raznih okolina te, uz školski neuspjeh, rizična djeca doživljavaju odbacivanje od nerizičnih vršnjaka. Tada se počinju intenzivnije družiti s rizičnim vršnjacima, a roditelji ih propuštaju adekvatno nadzirati. To dovodi do održavanja rizičnosti i usvajanja novih, težih oblika društveno neprihvatljiva ponašanja. Ponašanja koja su tijekom djetinjstva bila tzv. otvorena društveno neprihvatljiva ponašanja (npr. tučnjave, suprotstavljanje autoritetima) sve češće postaju tzv. prikrivena društveno neprihvatljiva ponašanja (npr. krađe, provale). ${ }^{1}$ 
DRUŠ. ISTRAŽ. ZAGREB GOD. 21 (2012), BR. 2 (116)

STR. $421-441$

ŠINCEK, D.

AJDUKOVIĆ, M.: RAZLIKE MEĐU..

\section{CILJEVI RADA}

METODA
Kod mladih s kasnim javljanjem, sve nepovoljne osobine postoje, ali su slabije izražene. To čini veliku razliku ovoga pristupa u odnosu na Moffittovu, koja smatra da su mladi čije je društveno neprihvatljivo ponašanje ograničeno na adolescenciju sličniji nerizičnim mladima. Patterson i suradnici smatraju pak da su mladi s kasnim javljanjem sličniji mladima s ranim javljanjem.

Istraživanja su se dosad pretežno usmjerila na mlade s ranim javljanjem (npr. Patterson i sur., 1992.) ili na mlade s ekstremnim oblicima ponašanja (npr. Stouthamer-Loeber i sur., 2002.). U skladu sa stajalištima o rizičnom i društveno neprihvatljivom ponašanju kao kontinuumu (npr. Koller-Trbović, 2004.), u ovom istraživanju usmjerili smo se na mlade koji pohađaju srednju školu. Kako ekstremno rizični mladići rijetko sudjeluju u redovitom školovanju, osobito u završnim razredima srednje škole, podatke o njima nismo prikupljali u ovom istraživanju. Stoga smo obuhvatili mlade koji očituju od niske preko srednje do visoke razine društveno neprihvatljivih ponašanja. $\mathrm{Za}$ one mlade koji manifestiraju srednje do visoke razine društveno neprihvatljiva ponašanja prikupili smo podatke o dobi prvoga javljanja takvih ponašanja i na temelju toga su formirane skupine mladih s ranim i s kasnim javljanjem društveno neprihvatljiva ponašanja. Provjerilo se postoje li razlike između ovako formiranih skupina mladića.

1. Provjeriti razlikuju li se mladi s ranim i kasnim javljanjem društveno neprihvatljiva ponašanja s obzirom na intenzitet samoiskazanih rizičnih i delinkventnih ponašanja te samoprocjenu agresivnosti i delinkventnosti.

2. Provjeriti razlikuju li se mladi niske razine društveno neprihvatljiva ponašanja od mladih $\mathrm{s}$ ranim i mladih $\mathrm{s}$ kasnim javljanjem društveno neprihvatljiva ponašanja s obzirom na sociodemografske osobine, samoprocjenu problema ponašanja i doživljavanja, percepciju roditeljskoga ponašanja te osobine vršnjačke skupine.

\section{Sudionici i postupak}

U ispitivanju je sudjelovao 661 mladić između 16 i 20 godina, s prosjekom od $17,76(\mathrm{SD}=0,678)$. Sudionici su učenici četiriju osječkih i triju zagrebačkih srednjih škola, polaznici trećih i četvrtih razreda srednje škole. Uzorak ispitanih škola bio je prigodan. Ispitivanje je bilo anonimno, a provodilo se grupno u trajanju od jednoga školskog sata.

Ispitanici su bili naknadno podijeljeni u tri skupine s obzirom na dob javljanja i ozbiljnost/težinu neprihvatljiva po- 
DRUŠ. ISTRAŽ. ZAGREB GOD. 21 (2012)

BR. 2 (116)

STR. $421-44$

ŠINCEK, D

AJDUKOVIĆ, M.

RAZLIKE MEĐU..

(1) TABLICA 1

Broi sudionika po različitim razinama društveno neprihvatliiva ponašanja našanja. Podaci o dobi javljanja neprihvatljiva ponašanja prikupljeni su odgovaranjem na Upitnik samoiskaza rizičnoga i delinkventnoga ponašanja mladih (SRDP-2007), koji je opisan u tekstu koji slijedi. Težina neprihvatljiva ponašanja naknadno je utvrđena na temelju pondera koje ima svako od ponašanja što se navodi u SRDP-2007 upitniku. Naime, tijekom razvoja upitnika skupina stručnjaka procjenjivala je rizičnost ponašanja opisanih u česticama. Pri tome su rabili skalu od 1 (nimalo rizično) do 9 (izrazito rizično ponašanje). Čestice kojima je na taj način pridodan ponder pet ili veći u ovom istraživanju jesu tzv. kriterijska ponašanja (opširnije o ponderima u Ručević i sur., 2009.). Mlade koji očituju takva ponašanja svrstali smo u skupinu sa srednjom i visokom razinom rizičnoga ponašanja (bilo je ukupno 434 takva sudionika). Sudionici koji nikada nisu manifestirali tzv. kriterijska ponašanja jesu mladi s niskom razinom društveno neprihvatljiva ponašanja te nisu uključeni u obradbu za prvi problem ovog istraživanja (njih ukupno 227). Od 434 sudionika iz skupine sa srednjom i visokom razinom društveno neprihvatljiva ponašanja formirane su dvije skupine: mladi s ranim javljanjem društveno neprihvatljiva ponašanja koji su s takvim ponašanjem počeli već u osnovnoj školi, dok su oni koji su se počeli tako ponašati u srednjoj školi mladi s kasnim javljanjem društveno neprihvatljiva ponašanja. U Tablici 1 prikazani su podaci o broju sudionika u pojedinim skupinama.

\begin{tabular}{lcccc}
\hline & & & $\begin{array}{c}\text { Postotak sudionika u skupinama sa } \\
\text { srednjom i visokom razinom društveno } \\
\text { neprihvatljiva ponašanja (N=434) }\end{array}$ \\
\hline $\begin{array}{l}\text { Mladi s niskom razinom društveno } \\
\text { neprihvatljiva ponašanja }\end{array}$ & 227 & 31,2 & \\
$\begin{array}{l}\text { Mladi s kasnim javljanjem društveno } \\
\text { neprihvatljiva ponašanja }\end{array}$ & 231 & 31,7 & 53,2 \\
$\begin{array}{c}\text { Mladi s ranim javljanjem društveno } \\
\text { neprihvatljiva ponašanja }\end{array}$ & 203 & 30,7 & 46,8 \\
\hline
\end{tabular}

\section{Varijable i način operacionalizacije}

Za svakog su sudionika prikupljeni sociodemografski podaci, podaci o rizičnom i delinkventnom ponašanju sudionika, internaliziranim problemima te o njegovoj percepciji vršnjaka i roditelja.

Prikupljeni sociodemografski podaci uključuju dob sudionika (izraženu u godinama), školski uspjeh na kraju prethodnog razreda, broj ponavljanih razreda, stupanj naobrazbe majke i oca, materijalne prilike u obitelji (od "1 - jako loše, znatno slabije od većine drugih" do "5 - odlične, znatno bolje od ve- 
DRUŠ. ISTRAŽ. ZAGREB GOD. 21 (2012), BR. 2 (116)

STR. $421-441$

ŠINCEK, D.

AJDUKOVIĆ, M.: RAZLIKE MEĐU. ćine drugih"), broj članova kućanstva, mjere izrečene braći i sestrama (rezultat je formiran tako da su se zbrajale ponderirane vrijednosti na pojedinim mjerama - od školskog ukora s ponderom 1 do zatvorske kazne s ponderom 6; odgovori sudionika bili su "0 - nitko, 1 - jedan brat ili sestra, 2 - dvoje ili više braće i sestara", a mogući raspon rezultata bio je od 0 do 42).

Podaci o rizičnom i društveno neprihvatljivom ponašanju prikupljeni su Samoiskazom rizičnog i društveno neprihvatljiva ponašanja te skalom eksternaliziranih problema iz upitnika Samoprocjene ponašanja mladih.

Samoiskaz rizičnog i delinkventnog ponašanja mladih (SRDP-2007, Ručević i sur., 2009.) sastoji se od 42 čestice koje tvore 7 faktora: Prekršajna i lakša delinkventna djela (11 čestica), Normativna nepoželjna ponašanja (7 čestica), Rizična spolna ponašanja (4 čestice), Korištenje i zlouporaba droga (6 čestica), Nasilnička ponašanja u bliskim odnosima (5 čestica), Teške krađe, provale i razbojništvo (6 čestica) te Suicidalna i autoagresivna ponašanja (3 čestice). U ovom istraživanju upotrijebljena je verzija koja se sastoji od 35 čestica (izostavljeni su faktori Rizična spolna ponašanja i Suicidalna i autoagresivna ponašanja). Sva ponašanja imaju određen ponder ili indeks težine (od 1 do 9 , podrobnije objašnjenje u Ručević i sur., 2009.). Pri tome je jedan označavao najmanje rizično, a devet najrizičnije ponašanje.

Sudionici su za svaku česticu odgovarali koliko su se često ponašali na opisani način te $u$ kojem su se razredu prvi put tako ponašali. Za čestinu su bili mogući sljedeći odgovori: " 0 = nikad, 1 = jedno ili dva takva ponašanja u životu, 2 = tri do četiri takva ponašanja $u$ životu, 3 = pet $i$ više takvih ponašanja u životu". Rezultat na pojedinoj čestici odredio se tako da se odgovor o čestini ponašanja množio s ponderom. Zbrojevi tih umnožaka činili su ukupan rezultat. Za ona ponašanja koja su sudionici tijekom života manifestirali barem jednom trebali su navesti razred u kojem su se prvi put tako ponašali.

Mogući raspon po podskalama bio je: Prekršajna i lakša delinkventna ponašanja od 0 do 147 (ostvareni raspon od 0 do 135); Nepoželjna normativna ponašanja od 0 do 36 (ostvareni raspon od 0 do 30); Korištenje ili zlouporaba psihoaktivnih tvari od 0 do 114 (ostvareni raspon od 0 do 96); Nasilničko ponašanje u bliskim odnosima od 0 do 129 (ostvareni raspon od 0 do 114); Teške krađe, provale i razbojništvo od 0 do 129 (ostvareni raspon od 0 do 126); za ukupan rezultat na Upitniku samoiskaza rizičnoga i delinkventnoga ponašanja od 0 do 555 (ostvareni raspon je od 0 do 407).

Pouzdanost unutarnje konzistencije (Cronbach-alpha) za cijeli upitnik i pet upotrijebljenih skala zadovoljavajuće je visoka i iznosi 0,908 za Ukupan rezultat, 0,833 za Prekršajna i lakša delinkventna ponašanja, 0,772 za Nepoželjna normativ- 
DRUŠ. ISTRAŽ. ZAGREB GOD. 21 (2012) BR. 2 (116)

STR. $421-44$

ŠINCEK, D AJDUKOVIĆ, M. RAZLIKE MEĐU. na ponašanja, 0,832 za Korištenje ili zlouporaba psihoaktivnih tvari, 0,649 za Nasilničko ponašanje u bliskim odnosima, 0,787 za Teške krađe, provale i razbojništvo.

Upitnik Samoprocjena ponašanja mladih (Youth Self-Report, Achenbach, 1991.) namijenjen je mjerenju eksternaliziranih i internaliziranih problema ponašanja i doživljavanja adolescenata. Sastoji se od 119 tvrdnji. Zadatak sudionika bio je da za svaku česticu procijeni koliko točno ona opisuje njegovo ponašanje i doživljavanje na skali od tri stupnja ("0 - nije točno; 1 - ponekad ili djelomično točno; 2 - potpuno točno").

Upitnik se sastoji od dvije skale - internalizirani i eksternalizirani problemi. Skala internaliziranih problema ima sedam podskala (povlačenje -7 čestica, somatske poteškoće -9 čestica, anksioznost/depresija - 16 čestica, socijalni problemi -8 čestica, problemi mišljenja - 7 čestica, problemi pozornosti - 8 čestica te samodestruktivni problemi ili problemi identiteta - 12 čestica), a podskale agresivnog (19 čestica) i delinkventnoga ponašanja (11 čestica) dio su skale eksternaliziranih problema.

Dobivene su sljedeće pouzdanosti unutarnje konzistencije (Cronbach-alpha) za pojedine dijelove upitnika: 0,831 za anksioznost/depresiju; 0,740 za povlačenje; 0,817 za somatske probleme; 0,701 za probleme mišljenja; 0,679 za probleme pozornosti; 763 za samodestruktivnost; 0,650 za socijalne probleme; 0,852 za agresivnost; 0,690 za delinkventno ponašanje; 0,881 za skalu eksternaliziranih problema; 0,889 za skalu internaliziranih problema; 0,946 za ukupan rezultat.

Utjecaj vršnjaka ispitao se Upitnikom devijantnosti vršnjaka i Upitnikom vršnjačkog utjecaja, koji su razvijeni za potrebe ovog istraživanja. Pri njihovoj konstrukciji pošlo se od tvrdnji iz SRDP-2007. Upitnici se sastoje od 18 čestica preuzetih iz skala Prekršajna i lakša delinkventna ponašanja i Nepoželjna normativna ponašanja. Zadatak sudionika u Upitniku devijantnosti vršnjaka jest procijeniti koliko se njegovih prijatelja, s kojima se redovito druži i s kojima izlazi, ponaša na opisani način (od "1 - nitko" do "4 - svi"), a u Upitniku vršnjačkog utjecaja koliko on doživljava/osjeća da ga njegovi prijatelji (njegovo "društvo") potiču ili koliko očekuju od njega da se on ponaša na opisane načine (od "0 - nimalo" do "3 - izrazito"). Ukupni rezultati dobiveni su zbrajanjem odgovora na pojedinim česticama. Pouzdanost unutarnje konzistencije (Cronbach-alpha) jest 0,925 (Upitnik devijantnosti vršnjaka) i 0,924 (Upitnik vršnjačkog utjecaja).

Percepcija roditeljskoga ponašanja mjerena je Upitnikom roditeljskoga ponašanja (URP, Brković i sur., 2005.; Keresteš i sur., 2006., prema Kuterovac Jagodić i sur., 2007.), koji se sastoji od 29 čestica koje opisuju ponašanja oca i majke, što čini tri faktora: Pozitivno roditeljstvo, Negativno roditeljstvo i Popustljivost. Zadatak sudionika bio je da na ljestvici od četiri stupnja 
DRUŠ. ISTRAŽ. ZAGREB GOD. 21 (2012), BR. 2 (116)

STR. $421-441$

ŠINCEK, D.

AJDUKOVIĆ, M.: RAZLIKE MEĐU. (od "1 - uopće nije točno" do "4 - potpuno točno") procijene ponašanje majke i oca. Upitnik je prilagođen upotrebi na adolescentnoj populaciji, pa su izbačene tri čestice, a dobivena je istovjetna faktorska struktura kakvu su na dječjoj populaciji dobivale autorice. Pouzdanosti unutarnje konzistencije (Cronbach-alpha) jesu: Pozitivno roditeljstvo 0,829 (majka), 0,849 (otac); Negativno roditeljstvo 0,749 (majka), 0,735 (otac); Popustljivost 0,655 (majka), 0,660 (otac). Ukupni rezultati na pojedinim podskalama formiraju se kao prosjek odgovora na pojedinim česticama te su ukupni rezultati određivani posebno za majke i posebno za očeve.

\section{Obradba podataka}

Radi odgovora na prvi problem, provedena je linearna diskriminacijska analiza kako bi se odgovorilo razlikuju li se dvije skupine sudionika (mladi s kasnim i mladi s ranim javljanjem društveno neprihvatljiva ponašanja) po samoiskazanim rizičnim i društveno neprihvatljivim ponašanjima te samoprocjenama delinkventnosti i agresivnosti. Radi odgovora na drugi problem, provedena je kanonička diskriminacijska analiza kako bi se utvrdilo razlikuju li se tri skupine po sociodemografskim osobinama, problemima ponašanja i doživljavanja te osobinama obitelji i vršnjaka.

\section{REZULTATI I RASPRAVA}

\section{Intenzitet samoiskazanih rizičnih i delinkventnih ponašanja i samoprocjena agresivnosti i delinkventnosti}

Provjerili smo razlikuju li se mladi s ranim i mladi s kasnim javljanjem društveno neprihvatljiva ponašanja po izraženosti svih ispitivanih oblika rizičnih i društveno neprihvatljivih ponašanja.

Rezultati diskriminacijske analize upućuju na postojanje značajnih razlika u izraženosti rizičnog i delinkventnih ponašanja mladih s ranim i mladih s kasnim javljanjem društveno neprihvatljiva ponašanja. Diskriminacijska funkcija je značajna (Tablica 2), a kanonička korelacija pokazuje da se $12 \%$ vari-

(1) TABLICA 2 jance te diskriminacijske funkcije može objasniti pripadnošću grupi. Iako su razlike značajne, one su male, na što osim pofunkcije stotka objašnjene varijance upućuje i Wilksova $\lambda$.

\begin{tabular}{cccccccc}
\hline Funkcija & $\begin{array}{c}\text { Karakteristični } \\
\text { korijen }\end{array}$ & $\begin{array}{c}\text { Kanonička } \\
\text { korelacija }\end{array}$ & Wilksova $\lambda$ & $\chi^{2}$ & df & $p$ \\
\hline 1 & 0,137 & 0,347 & 0,880 & 51,279 & 7 & $<0,001$
\end{tabular}


DRUŠ. ISTRAŽ. ZAGREB GOD. 21 (2012), BR. 2 (116),

STR. $421-44$

ŠINCEK, D

AJDUKOVIĆ, M. RAZLIKE MEĐU.. društveno neprihvatljiva ponašanja $u$ adolescenciji. Po mišljenju ove autorice, mladi s kasnim javljanjem društveno neprihvatljiva ponašanja, jednom kad se počnu tako ponašati, po njegovoj izraženosti uskoro dostižu mlade s ranim javljanjem društveno neprihvatljiva ponašanja. Stoga Moffitt (1993.) smatra da jedino longitudinalnim praćenjem možemo razvrstati osobe s obzirom na dob javljanja ponašanja.

Rezultati (Tablice 3 i 4) pokazuju dvije važne informacije - veće doprinose prikrivenih i nasilnih ponašanja objašnjenju pripadnosti mladima s ranim javljanjem društveno neprihvatljiva ponašanja.

To je u skladu s istraživanjima (Patterson i Yoerger, 2004.) koja pokazuju da je za ove mlade karakterističnija stabilna i visoka razina agresivna ponašanja od rane dobi do adolescencije. Stoga je očekivano da je u ovoj skupini izraženo nasilno društveno neprihvatljivo ponašanje. Nasilna ponašanja lako su uočljiva, pa za njih rabimo pojam "otvorena" (vidljiva npr. roditeljima i nastavnicima).

Istraživanja (Patterson i Yoerger, 2004.) pokazuju i da mladi s ranim javljanjem društveno neprihvatljiva ponašanja tijekom odrastanja usvajaju nove i sve složenije oblike društveno neprihvatljivih ponašanja. Kasnije usvojena ponašanja u većoj se mjeri mogu svrstati u prikrivena ponašanja. U prikrivena ponašanja mogu se ubrojiti npr. krađe, provale.

Pripadnost mladima s kasnim javljanjem društveno neprihvatljiva ponašanja može se više objasniti uživanjem droge, normativnim nepoželjnim ponašanjem i agresivnim ponašanjem. Dakle, mladi s kasnim javljanjem društveno neprihvatljiva ponašanja skloniji su npr. bježanju iz škole ili konzumiranju alkoholnih pića, što su ponašanja koja su pod značajnim utjecajem vršnjaka. S obzirom na teorijska objašnjenja razvoja rizičnoga ponašanja u ovoj skupini (Patterson i Yoerger, 2004.), koja upućuju na velik doprinos vršnjačkih utjecaja, to je očekivano. Agresivnost je također značajnija u ovoj skupini. Ako razmotrimo čestice, vidimo da skala Agresivnosti iz upitnika Samoprocjene ponašanja mladih zapravo obuhvaća blaže oblike manifestiranja agresivnosti, u usporedbi s česticama podskale SRDP-2007, koja se odnosi na nasilje u bliskim odnosima. Kako Patterson i sur. (1992.) pokazuju da se rizično ponašanje razvija od jednostavnijega prema složenijem, moguće je da mladi s kasnim javljanjem društveno neprihvatljiva ponašanja prolaze takav, "zakašnjeli" razvoj rizičnoga i društveno neprihvatljiva ponašanja.

Drugo je moguće objašnjenje da mlade s ranim javljanjem društveno neprihvatljiva ponašanja karakteriziraju ponašanja koja predstavljaju veći rizik za kasniji razvoj pojedinca, a mlade s kasnim javljanjem društveno neprihvatljiva ponašanja ponašanja koja su povezana s manjim rizikom za kasnije neprilagođeno funkcioniranje. 
-2 TABLICA 3

Standardizirani diskriminaciiski koeficiienti (K) i diskriminacijski

faktori (F)

(1) TABLICA 4

Centroidi grupa

Skupine s različitom dobi javljanja

Skale SRDP-2007

Prekršajna i lakša delinkventna djela

Normativna nepoželjna ponašanja

$0,779 \quad 0,922$

Uživanje i zlouporaba droga

$-0,094 \quad 0,351$

Nasilnička ponašanja u bliskim odnosima

$-0,120 \quad 0,379$

Teške krađe, provale i razbojništvo

$0,158 \quad 0,512$

$0,365 \quad 0,732$

Skale za eksternalizirane probleme YSR

Agresivno ponašanje

$-0,133 \quad 0,334$

Delinkventno ponašanje

Skupina s kasnim javljanjem društveno neprihvatljiva ponašanja

Skupina s ranim javljanjem društveno neprihvatljiva ponašanja

U Tablici 5 prikazani su rezultati točnih klasifikacija sudionika u dvije skupine različite dobi javljanja. Rezultati pokazuju $62,7 \%$ točnih klasifikacija. Podsjećamo na to da je u poduzorku sudionika s društveno neprihvatljivim ponašanjem

(1) TABLICA 5

Sumarna tablica

$53,2 \%$ mladih s kasnim javljanjem društveno neprihvatljiva ponašanja, a 46,8\% je mladih s ranim javljanjem takva ponašanja.

\begin{tabular}{|c|c|c|c|}
\hline \multirow[b]{2}{*}{ Originalno } & \multicolumn{3}{|c|}{ Predviđeno pripadanje kategoriji } \\
\hline & $\begin{array}{r}\text { Mladi s kasnim } \\
\text { javljanjem } \\
\text { društveno nepri- } \\
\text { atljiva ponašanja }\end{array}$ & $\begin{array}{r}\text { Mladi s ranim } \\
\text { javljanjem } \\
\text { društveno nepri- } \\
\text { hvatljiva ponašanja }\end{array}$ & Ukupno \\
\hline \multicolumn{4}{|l|}{ Apsolutni broj } \\
\hline $\begin{array}{l}\text { Mladi s kasnim javljanjem } \\
\text { društveno neprihvatljiva ponašanja } \\
\text { Mladi s ranim javljanjem }\end{array}$ & 123 & 64 & 187 \\
\hline društveno neprihvatljiva ponašanja & 87 & 131 & 218 \\
\hline \multicolumn{4}{|l|}{ Postotak } \\
\hline $\begin{array}{l}\text { Mladi s kasnim javljanjem } \\
\text { društveno neprihvatljiva ponašanja } \\
\text { Mladi s ranim javljanjem }\end{array}$ & 65,8 & 34,2 & 100,0 \\
\hline društveno neprihvatljiva ponašanja & 39,9 & 60,1 & 100,0 \\
\hline
\end{tabular}

Iz Tablice 5 vidimo da je kod mladih s kasnima javljanjem društveno neprihvatljiva ponašanja $65,8 \%$ točnih klasifikacija, a kod mladih s ranim javljanjem društveno neprihvatljiva ponašanja $60,1 \%$. Dakle, na temelju diskriminacijskih varijabli ipak možemo povećati broj točnih klasifikacija u odnosu na slučajan raspored u skupine. Iako poboljšanje klasifikacije nije veliko, nije ni zanemarivo. Osobito nam se takvim čini ako imamo na umu pretpostavku Terrie Moffitt (1993.) da ove 
DRUŠ. ISTRAŽ. ZAGREB GOD. 21 (2012) BR. 2 (116)

STR. 421-44

ŠINCEK, D

AJDUKOVIĆ, M.

RAZLIKE MEĐU..

(1) TABLICA 6

Utvrđivanje razlika među mladima s kasnim i ranim

javlianiem društveno

neprihvatliiva

ponašanja skupine u ovoj dobi nije moguće razlikovati na temelju manifestnoga ponašanja. Treba imati na umu i to da $u$ ovom istraživanju uspoređujemo skupine srednje do visoke razine društveno neprihvatljiva ponašanja. Moguće je da bi kombinacija razina rizičnosti (uključivanje i skupine ekstremnog rizika) i dobi javljanja poboljšalo klasifikaciju. Naime, način definiranja kriterija za društveno neprihvatljiva ponašanja u međunarodnim istraživanjima na koje se referiramo (npr. 2-3 uhićenja do 14 ili nakon 14 godina) značajno se razlikuje od kriterija u ovom istraživanju, koje je bar jedno ponašanje s ponderom pet ili većim (ponašanja srednje ili visoke razine rizičnosti) manifestirano tijekom osnovne škole (za mlade s ranim javljanjem društveno neprihvatljiva ponašanja), odnosno nakon završetka osnovne škole za mlade s kasnim javljanjem društveno neprihvatljiva ponašanja. Prema strožim kriterijima koje predlaže npr. Moffitt (1993.), moguće je da bi svi naši sudionici bili mladi s kasnim javljanjem društveno neprihvatljiva ponašanja. Naše je stajalište, pak, da treba razmotriti razne mogućnosti klasificiranja skupina i pronaći onu klasifikaciju koja omogućuje najbolje prepoznavanje specifičnih činitelja rizika i njihovih doprinosa.

Diskriminacijska analiza potvrdila je da se skupine razlikuju po rizičnim i društveno neprihvatljivim ponašanjima. Kako bismo provjerili u kojem smjeru idu razlike među skupinama, proveli smo t-testove za pojedine skale. Rezultati su navedeni u Tablici 6 . Na temelju testiranih razlika između aritmetičkih sredina možemo zaključiti da se mladi s ranim i s kasnim javljanjem društveno neprihvatljiva ponašanja značajno razlikuju po svim oblicima ponašanja praćenog u ovom istraživanju. U svim situacijama mladi s ranim javljanjem društveno neprihvatljiva ponašanja pokazali su veću izraženost rizičnoga i društveno neprihvatljiva ponašanja.

\begin{tabular}{|c|c|c|c|c|c|c|c|}
\hline \multirow[b]{2}{*}{ Skale } & \multicolumn{3}{|c|}{$\begin{array}{r}\text { Mladi s kasnim jav- } \\
\text { ljanjem društveno } \\
\text { neprihvatljiva } \\
\text { ponašanja }\end{array}$} & \multicolumn{3}{|c|}{$\begin{array}{r}\text { Mladi s ranim jav- } \\
\text { ljanjem društveno } \\
\text { neprihvatljiva } \\
\text { ponašanja }\end{array}$} & \multirow{2}{*}{$\begin{array}{l}\mathrm{t}(\mathrm{df}= \\
(=432)\end{array}$} \\
\hline & $\mathrm{M}$ & SD & TR & $\mathrm{M}$ & SD & TR & \\
\hline \multicolumn{8}{|l|}{ Skale SRDP-2007 } \\
\hline Prekršajna i lakša delinkventna ponašanja & 25,36 & 18,967 & $0-88$ & 43,26 & 31,138 & $0-135$ & $-7,32^{* *}$ \\
\hline Nepoželjna normativna ponašanja & 19,17 & 6,867 & $0-30$ & 21,10 & 7,203 & $1-30$ & $-2,84^{* *}$ \\
\hline Uživanje ili zlouporaba psihoaktivnih tvari & 7,71 & 15,988 & $0-96$ & 12,90 & 21,659 & $0-96$ & $-2,86^{* *}$ \\
\hline Nasilničko ponašanje u bliskim odnosima & 4,56 & 9,822 & $0-54$ & 10,55 & 18,724 & $5-114$ & $-4,24^{* *}$ \\
\hline Teža krađa, provale, razbojništvo & 2,85 & 7,694 & $5-57$ & 11,70 & 21,137 & $0-126$ & $-5,93^{* *}$ \\
\hline \multicolumn{8}{|l|}{ Eksternalizirane skale YSR } \\
\hline Agresivno ponašanje & 9,96 & 5,786 & $0-25$ & 11,44 & 6,041 & $2-31$ & $-2,53^{*}$ \\
\hline Delinkventno ponašanje & 4,96 & 2,705 & $0-16$ & 5,88 & 3,274 & $0-19$ & $-3,16^{* *}$ \\
\hline
\end{tabular}

${ }^{*} \mathrm{p}<0,05 ;{ }^{* *} \mathrm{p}<0,01$ 


\section{Razina i javljanje društveno neprihvatliiva ponašanja s obzirom na moguće činitelje rizika}

Provjerili smo razlikuju li se mladi niske razine društveno neprihvatljiva ponašanja te mladi s kasnim javljanjem društveno neprihvatljiva ponašanja i mladi s ranim javljanjem društveno neprihvatljiva ponašanja s obzirom na neke sociodemografske osobine, probleme ponašanja i doživljavanja, percepciju roditeljskoga ponašanja te osobine vršnjaka. U tu svrhu provedena je kanonička diskriminacijska analiza. Naime, prethodna analiza poslužila nam je kako bismo provjerili možemo li uopće razlikovati dvije skupine sa srednjom i visokom razinom društveno neprihvatljiva ponašanja prema izraženosti takvih ponašanja. U ovoj analizi željelo se provjeriti mogu li se tri skupine sudionika u ovom istraživanju razlikovati na temelju različitih činitelja rizika koji su vezani uz obilježja samih sudionika, obilježja njihovih obitelji i vršnjaka.

Kanonička diskriminacijska analiza pokazala je da je prva diskriminacijska funkcija značajna, a druga neznačajna (Tablica 7). Kanonička korelacija prve diskriminacijske fukncije

(1) TABLICA 7 Značajnost kanoničke diskriminacijske funkcije pokazuje da se $26,11 \%$ varijance te diskriminacijske funkcije može objasniti pripadnošću grupi. Rezultati će se komentirati samo u odnosu na ovu značajnu funkciju.

\begin{tabular}{lccccccc}
\hline Funkcija & $\begin{array}{c}\text { Karakteristični } \\
\text { korijen }\end{array}$ & $\begin{array}{c}\text { Kanonička } \\
\text { korelacija }\end{array}$ & Wilksova $\lambda$ & $\chi^{2}$ & df & $\mathrm{p}$ \\
\hline 1 & 0,354 & 0,511 & 0,686 & 99,030 & 48 & $<0,001$ \\
2 & 0,077 & 0,267 & 0,929 & 19,416 & 23 & $>0,010$ \\
\hline
\end{tabular}

Vidi se da razlikovanju skupina (Tablice 8 i 9) najviše pridonose činitelji rizika vezani uz vršnjake. S obzirom na to koliko Patterson i sur. (1992., 2004.) naglašavaju ulogu vršnjaka u povećavanju rizičnosti ponašanja mladih društveno neprihvatljiva ponašanja, ovakav se rezultat očekivao. Razlikovanju triju skupina značajno pridonose i iskazani problemi ponašanja i doživljavanja mjereni upitnikom Samoprocjena ponašanja mladih, kao i negativno roditeljstvo oca (jedan od tri faktora Upitnika roditeljskoga ponašanja). Sociodemografske osobine slabo su pridonosile razlikovanju ovih triju skupina diskriminacijskom analizom, što je u skladu s našim pretpostavkama. Iznenađuje nizak doprinos percepcije roditeljskoga ponašanja. Objašnjenje toga vjerojatno treba tražiti u razvojnoj dobi naših sudionika i činjenici da roditeljska ponašanja pred kraj adolescencije ipak imaju manju ulogu nego u djetinjstvu ili u ranoj adolescenciji. Naime, istraživanja na kojima smo temeljili očekivanje visokoga doprinosa u objašnjenju rizičnoga i društveno neprihvatljiva ponašanja, kao i moguć- 
DRUŠ. ISTRAŽ. ZAGREB GOD. 21 (2012) BR. $2(116)$

STR. $421-44$

ŠINCEK, D

AJDUKOVIĆ, M.

RAZLIKE MEĐU.

(1) TABLICA 8

Standardizirani diskriminacijski koeficijenti (K) i diskriminacijski faktori ( $F$ tinjstva. Stoga ne iznenađuje što su ona pokazala veliko značenje roditeljskih ponašanja. Nadalje, smatramo da ovo malo značenje roditeljskih ponašanja za razlikovanje skupina treba razmotriti i u kontekstu činjenice da se radi o percepciji roditeljskoga ponašanja. Treba imati na umu realističnost te koncepcije. Mladi su vrlo vjerojatno subjektivno (i blagonaklono) opisivali ponašanje roditelja. Ricijaš je (2009.) utvrdio da više od $75 \%$ sudionika (mladih s različitim sankcijama izrečenim zbog počinjenih prekršajnih i kaznenih djela) procjenjuje odnose u svojoj obitelji kao uglavnom ili jako dobre te je uglavnom ili potpuno zadovoljno odnosima u svojoj obitelji. Takve podatke smatra indikatorom neprepoznavanja nepovoljnih obiteljskih okolnosti u mladih društveno neprihvatljiva ponašanja, kao i neprepoznavanja nepoželjnih efekata takvih roditeljskih ponašanja na društveno neprihvatljivo ponašanje mladih. Oregonska studija mladih koristila se procjenama roditeljskoga ponašanja koje daju objektivni procjenjivači, što nam može objasniti razlike $u$ našim i njihovim rezultatima.

\begin{tabular}{|c|c|c|c|c|}
\hline \multirow[b]{2}{*}{ Diskriminacijske varijable (upitnik) } & \multicolumn{2}{|c|}{ Prva funkcija } & \multicolumn{2}{|c|}{ Druga funkcija } \\
\hline & K & F & K & $\mathrm{F}$ \\
\hline Rizičnost vršnjaka (Upitnik devijantnosti vršnjaka) & 0,571 & $0,807^{*}$ & $-0,300$ & $-0,097$ \\
\hline Vršnjački pritisak (Upitnik vršnjačkoga pritiska) & 0,341 & $0,660^{*}$ & 0,112 & 0,036 \\
\hline Problemi pozornosti (Samoprocjena ponašanja mladih) & 0,205 & $0,444^{*}$ & 0,256 & 0,198 \\
\hline Negativno roditeljstvo otac (Upitnik roditeljskoga ponašanja) & 0,195 & $0,379 *$ & $-0,407$ & $-0,262$ \\
\hline Samodestruktivnost (Samoprocjena ponašanja mladih) & 0,045 & $0,349^{*}$ & 0,645 & 0,250 \\
\hline Anksioznost i depresija (Samoprocjena ponašanja mladih) & $-0,046$ & $0,321^{*}$ & 0,171 & 0,108 \\
\hline Problemi mišljenja (Samoprocjena ponašanja mladih) & 0,037 & $0,291^{*}$ & $-0,109$ & $-0,096$ \\
\hline najke (Upitnik roditeljskoga ponašanja) & 0,230 & $0,261^{*}$ & $-0,061$ & 0,097 \\
\hline Somatski problemi (Samoprocjena ponašanja mladih) & 0,020 & $0,260^{*}$ & $-0,158$ & 0,040 \\
\hline Negativno roditeljstvo majka (Upitnik roditeljskoga pona & 0,051 & $0,256^{*}$ & 0,016 & $-0,182$ \\
\hline Mjere izrečene braći i sestrama (Sociodemografski upitnik) & 0,109 & $0,220^{*}$ & 0,139 & $-0,087$ \\
\hline Broj $\mathrm{p}$ & 0,249 & $0,215^{*}$ & 0,268 & 0,105 \\
\hline teljskoga ponašanja) & 0,082 & $-0,128^{*}$ & 0,399 & $-0,044$ \\
\hline Povlačenje (Samoprocjena ponašanja mladih) & $-0,098$ & $0,079 *$ & $-0,244$ & $-0,058$ \\
\hline Socijalni problemi (Samoprocjena ponašanja mladi & $-0,321$ & $0,068^{*}$ & $-0,121$ & $-0,048$ \\
\hline Stupanj obrazovanja oca (Sociodemografski upitnik) & 0,060 & 0,060 & 0,432 & $-0,518^{*}$ \\
\hline i upitnik) & 0,033 & $-0,015$ & 0,370 & $0,285^{*}$ \\
\hline cioden & $-0,009$ & 0,074 & $-0,392$ & $-0,248^{*}$ \\
\hline Stupanj obrazovanja majke (Sociodemografski upitnik) & 0,000 & 0,046 & 0,035 & $-0,218^{*}$ \\
\hline Popustljivost otac (Upitnik roditeljskoga ponašanja) & $-0,055$ & 0,095 & 0,346 & $0,205^{*}$ \\
\hline Pozitivno roditeljstvo majka (Upitnik roditeljskoga ponaša & 0,023 & $-0,052$ & $-0,516$ & $-0,153^{*}$ \\
\hline Materijalne prilike obitelji (Sociodemografski upitnik) & $-0,133$ & $-0,066$ & $-0,078$ & $-0,126^{*}$ \\
\hline Školski uspjeh (Sociodemografski upitnik) & 0,127 & $-0,065$ & 0,326 & $0,092^{*}$ \\
\hline
\end{tabular}

U Tablici 10 prikazani su rezultati točnih klasifikacija sudionika u tri skupine različite izraženosti i dobi javljanja rizičnoga ponašanja. Rezultati pokazuju visokih 56,7\% točnih klasifikacija. Točnost klasifikacija najveća je kod mladih niske ra- 
zine društveno neprihvatljiva ponašanja $(77,6)$, a najmanja kod mladih s kasnim javljanjem društveno neprihvatljiva ponaša-

(1) TABLICA 9

Centroidi grupa nja, $\mathrm{u}$ kojoj je podjednaka vjerojatnost da se po slučaju sudionik rasporedi u tu skupinu $(34,5 \%)$.

Skupine

Funkcija 1 Funkcija 2

Mladi niske razine društveno neprihvatljiva ponašanja

$-0,718$

0,095

Skupina s kasnim javljanjem društveno neprihvatljiva ponašanja

0,243

$-0,402$

Mladi s ranim javljanjem društveno neprihvatljiva ponašanja

0,656

0,275

Predviđeno pripadanje kategoriji

\begin{tabular}{rrrr}
\hline Mladi niske & Mladi s kasnim & Mladi s ranim & \\
razine & javljanjem & javljanjem & \\
društveno & društveno & društveno & \\
neprihvatljiva & neprihvatljiva & neprihvatljiva \\
ponašanja & ponašanja & ponašanja & Ukupno \\
\hline
\end{tabular}

Originalno 83 13 11 107

Apsolutni broj
Mladi niske razine društveno neprihvatljiva ponašanja Mladi s kasnim javljanjem društveno neprihvatljiva ponašanja

Mladi s ranim javljanjem društveno neprihvatljiva ponašanja

Postotak

Mladi niske razine društveno neprihvatljiva ponašanja Mladi s kasnim javljanjem društveno neprihvatljiva ponašanja Mladi s ranim javljanjem društveno neprihvatljiva ponašanja

$56,7 \%$ originalnih ispitanika točno je klasificirano prema kategorijama

i) TABLICA 10 Sumarna tablica
Mladi s kasnim javljanjem društveno neprihvatljiva ponašanja, kako smo navodili u uvodu, i u teorijskim su koncepcijama definirani kao "granični" (Patterson i sur., 1992.; Moffitt, 1993.). Zapravo, u ovom radu polazimo od ideje o kontinuumu rizičnoga i društvenoga ponašanja od ponašanja niske razine rizika do ponašanja ekstremne razine rizika. Kasno javljanje neprihvatljiva ponašanja smatramo manje rizičnim od ranoga. U skladu s tom idejom i s idejama drugih istraživača navedenih na početku ovog ulomka, mladi s kasnim javljanjem društveno neprihvatljiva ponašanja nalaze se "između" mladih s niskom razinom društveno neprihvatljiva ponašanja i mladih s ranim javljanjem društveno neprihvatljiva ponašanja. Smatramo da dijele neke zajedničke osobine s obje skupine, pa stoga ne začuđuje što je u ovoj skupini dosta netočnih klasifikacija. 
DRUŠ. ISTRAŽ. ZAGREB GOD. 21 (2012), BR. 2 (116)

STR. 421-44

ŠINCEK, D

AJDUKOVIĆ, M.

RAZLIKE MEĐU..

(1) TABLICA 11

Jednostavna analiza varijance za varijable povezane s prvom diskriminaciijskom funkcijom
Dodatno objašnjenje jest odabir činitelja rizika (obilježja koje smo pratili). Moguće je da smo, povodeći se za dosadašnjim istraživanjima, odabrali činitelje rizika koji omogućuju bolje razlikovanje mladih niske razine društveno neprihvatljiva ponašanja od mladih s ranim javljanjem društveno neprihvatljiva ponašanja. Mladi s kasnim javljanjem društveno neprihvatljiva ponašanja do sada su nedovoljno istraživani, pa ne iznenađuje ako su neki bitni činitelji rizika karakteristični za ovu skupinu izostavljeni. Smatramo da u idućim istraživanjima trebamo uključiti i način provođenja slobodnoga vremena, doprinos normi vršnjaka bihevioralnim namjerama sudionika i slično.

Provedene su jednostavne analize varijance za šesnaest varijabli povezanih s prvom diskriminacijskom funkcijom. Rezultati tih analiza prikazani su u Tablici 11. Varijable vezane uz percepciju vršnjaka omogućuju razlikovanje svih triju skupina (mladi niske razine rizičnosti društveno neprihvatljiva ponašanja imaju najpovoljnije uvjete, a mladi s ranim javljanjem društveno neprihvatljiva ponašanja najnepovoljnije). Ostale varijable pokazuju ponekad da se dvije skupine srednje do visoke razine društveno neprihvatljiva ponašanja ne razlikuju međusobno, no imaju izraženije činitelje rizika nego mladi niske razine društveno neprihvatljiva ponašanja.

\begin{tabular}{|c|c|c|c|c|c|c|c|c|c|c|}
\hline \multirow[b]{2}{*}{ Skale i podskale } & \multicolumn{3}{|c|}{$\begin{array}{r}\text { Mladi niske razine } \\
\text { društveno } \\
\text { neprihvatljiva } \\
\text { ponašanja }\end{array}$} & \multicolumn{3}{|c|}{$\begin{array}{r}\text { Mladi s kasnim jav- } \\
\text { ljanjem društveno } \\
\text { neprihvatljiva } \\
\text { ponašanja }\end{array}$} & \multicolumn{3}{|c|}{$\begin{array}{r}\text { Mladi s ranim jav- } \\
\text { ljanjem društveno } \\
\text { neprihvatljiva } \\
\text { ponašanja }\end{array}$} & \multirow{2}{*}{$\begin{array}{r}F \\
d f=2 / 658\end{array}$} \\
\hline & $\mathrm{M}$ & SD & TR & $\mathrm{M}$ & SD & TR & $\mathrm{M}$ & SD & TR & \\
\hline Rizičnost vršnjaka & 32,56 & 9,015 & $19-76$ & 39,16 & 10,250 & $19-76$ & 43,38 & 10,631 & $23-76$ & $63,367^{* *}$ \\
\hline Vršnjački pritisak & 5,60 & 6,820 & $0-54$ & 10,52 & 8,831 & $0-54$ & 14,08 & 11,273 & $0-54$ & $57,537^{* *}$ \\
\hline Anksioznost/depresija & 3,99 & 4,624 & $0-32$ & 5,27 & 4,663 & $0-25$ & 5,74 & 4,891 & $0-24$ & $8,042^{* *}$ \\
\hline Problemi mišljenja & 1,69 & 2,141 & $0-14$ & 2,75 & 2,601 & $0-12$ & 2,97 & 2,657 & $0-12$ & $15,791^{* *}$ \\
\hline Povlačenje & 2,48 & 2,706 & $0-14$ & 2,63 & 2,476 & $0-12$ & 2,59 & 2,447 & $0-12$ & 0,199 \\
\hline Problemi pozornosti & 4,30 & 2,908 & $0-16$ & 5,57 & 2,843 & $0-15$ & 6,08 & 2,871 & $0-16$ & $22,526^{* *}$ \\
\hline Samodestruktivnost & 2,03 & 2,995 & $0-24$ & 2,92 & 2,708 & $0-13$ & 3,56 & 3,572 & $0-20$ & $12,874^{* *}$ \\
\hline Socijalni problemi & 2,24 & 2,528 & $0-16$ & 2,46 & 2,047 & $0-10$ & 2,48 & 2,186 & $0-12$ & 0,771 \\
\hline Somatski problemi & 1,30 & 2,241 & $0-18$ & 1,83 & 2,602 & $0-13$ & 2,31 & 3,177 & $0-18$ & $7,298^{* *}$ \\
\hline Pozitivno roditeljstvo otac & 2,72 & 0,614 & $1-4$ & 2,64 & 0,582 & $1-4$ & 2,60 & 0,546 & $1-4$ & 1,731 \\
\hline Negativno roditeljstvo majka & 1,63 & 0,439 & $1-4$ & 1,81 & 0,441 & $1-3$ & 1,82 & 0,434 & $1-4$ & $11,579 * *$ \\
\hline Negativno roditeljstvo otac & 1,64 & 0,445 & $1-3$ & 1,83 & 0,475 & $1-4$ & 1,84 & 0,474 & $1-3$ & $10,508^{* *}$ \\
\hline Popustljivost majka & 2,30 & 0,723 & $1-4$ & 2,39 & 0,698 & $1-4$ & 2,49 & 0,686 & $1-3$ & $3,620 * *$ \\
\hline Broj ponavljanih razreda & 0,09 & 0,300 & $0-2$ & 0,20 & 0,479 & $0-3$ & 0,21 & 0,498 & $0-3$ & $5,569^{* *}$ \\
\hline Mjere braće i sestara & 0,08 & 0,554 & $0-6$ & 0,64 & 2,353 & $0-22$ & 0,60 & 1,982 & $0-16$ & $6,712^{* *}$ \\
\hline
\end{tabular}

${ }^{*} \mathrm{p}<0,05 ;{ }^{* *} \mathrm{p}<0,01$

\section{OPĆA RASPRAVA}

Način formiranja skupina osigurao je da se mladi s ranim i s kasnim javljanjem društveno neprihvatljiva ponašanja mogu razlikovati samo po dobi javljanja, tj. imati istu razinu izraženosti toga ponašanja, ali različitu dob njegova prvog javljanja. 
DRUŠ. ISTRAŽ. ZAGREB GOD. 21 (2012), BR. 2 (116)

STR. $421-441$

ŠINCEK, D.

AJDUKOVIĆ, M.: RAZLIKE MEĐU..
No istraživanja (Patterson i sur., 1992.; Patterson i Yoerger, 2004.) nam daju osnovu da pretpostavimo kako će mladi s ranim javljanjem društveno neprihvatljiva ponašanja imati veću izraženost rizičnog i društveno neprihvatljiva ponašanja. Rezultati ovog istraživanja idu u prilog toj pretpostavci.

Pripadnost mladima s ranim javljanjem društveno neprihvatljiva ponašanja više je određena Prekršajnim i lakšim delinkventnim ponašanjem, činjenjem Težih krađa, provala i razbojništava i Nasilničkim ponašanjem u bliskim odnosima (na upitniku SRDP-2007) te samoprocjenom Delinkventnosti (na upitniku Samoprocjene ponašanja mladih). Pripadnost mladima s kasnim javljanjem društveno neprihvatljiva ponašanja više je određena Konzumiranjem i zloupotrebom droge, Normativnim nepoželjnim ponašanjem (na upitniku SRDP-2007) i samoprocjenom Agresivna ponašanja (na upitniku Samoprocjene ponašanja mladih).

Ti podaci idu u prilog pretpostavkama i rezultatima Pattersona i njegovih suradnika (npr. Patterson i sur., 1992., Reid i sur., 2004.) o sve ozbiljnijem i prikrivenijem ponašanju (prikriveno za obitelj i nastavnike) u mladih s ranim javljanjem društveno neprihvatljiva ponašanja s povećanjem dobi. Mladi s ranim javljanjem društveno neprihvatljiva ponašanja $u$ ovom istraživanju više čine kaznena djela koja se mogu svrstati u krađe, provale, razbojništva, oštećenja tuđih stvari te nasilje bilo uzrokovano netrpeljivošću prema nekim skupinama (npr. Romima ili homoseksualcima), bilo prema ljudima s kojima su u bliskim odnosima. Od ponašanja koja karakteriziraju tu skupinu, jedino su nasilna ponašanja prema bližnjima "vidljiva" ukućanima. Za ostala ponašanja karakteristično je da se odvijaju izvan kuće, pa se mladi trude prikriti takva svoja ponašanja, svjesni da ona izazivaju neželjene reakcije društva.

Moffitt (1993.) upozorava da će se mladi s ranim javljanjem društveno neprihvatljiva ponašanja u većoj mjeri ponašati nasilno. Podatak iz našeg istraživanja ide u prilog toj konstataciji. Patterson i Yoerger (2004.) također pokazuju da je za ove mlade karakteristična stabilna i visoka razina agresivnoga ponašanja od djetinjstva do adolescencije. Za razliku od čestica na skali Agresivnosti iz Samoprocjene ponašanja mladih, nasilna ponašanja na ovim podskalama znatno su ozbiljnija. Agresivna ponašanja uključena u podskalu Agresivnosti "preblaga" su i ovi mladi su ih "prerasli". Stoga su za njih karakterističniji teži oblici ponašanja sadržani u podskali Nasilničkoga ponašanja prema bliskim osobama.

Pripadnost mladima s kasnim javljanjem društveno neprihvatljiva ponašanja više je određena Nepoželjnim normativnim ponašanjem, Konzumiranjem i zloupotrebom droge (na SRDP-2007) te Agresivnošću (na Achebachovu upitniku). Uz iznimku konzumiranja droge, za mlade s kasnim javlja- 
DRUŠ. ISTRAŽ. ZAGREB GOD. 21 (2012) BR. 2 (116)

STR. $421-44$

ŠINCEK, D

AJDUKOVIĆ, M. RAZLIKE MEĐU.. njem društveno neprihvatljiva ponašanja karakterističniji su blaži oblici ponašanja.

Iako je diskriminacijska funkcija bila značajna, kanonička korelacija pokazuje da se samo $12 \%$ varijance diskriminacijske funkcije može objasniti pripadnošću skupini. Dakle, iako razlike postoje, one su male i donekle potvrđuju upozorenja Terrie Moffitt (1993.) da je mlade s ranim i kasnim javljanjem društveno neprihvatljiva ponašanja teško razlikovati u adolescenciji na temelju opaženoga ponašanja.

U razlikovanju triju skupina sudionika na temelju činitelja rizika pokazalo se da jedna diskriminacijska funkcija opisuje njihovo razlikovanje. Na osnovi te značajne diskriminacijske funkcije izdvojili smo varijable koje pridonose razlikovanju skupina. Cinitelji rizika koji najviše pridonose razlikovanju triju skupina vezani su uz vršnjake te probleme ponašanja i doživljavanja. Važnost vršnjaka prepoznaju brojna istraživanja i teorijska objašnjenja društveno neprihvatljiva ponašanja, uključujući i pristup taksonomiji za koji se zalaže Terrie Moffitt (1993.) te istraživači iz Oregonske studije mladih (Snyder, 2004.; Patterson i Yoerger, 2004.). Problemi ponašanja i doživljavanja (kao što su problemi mišljenja, problemi pozornosti, anksioznost/depresivnost i samodestruktivnost koji su se pokazali kao varijable koje značajno pridonose razlikovanju triju skupina) također su ranije prepoznati kao važni činitelji rizika (npr. Farrington, 2003.).

Relativno iznenađuje što među varijablama koje najviše pridonose razlikovanju skupina nisu zastupljene varijable vezane uz roditeljstvo. Ranija istraživanja pokazuju veliko značenje roditeljskoga ponašanja - discipliniranja, nadzora, prihvaćanja i odbacivanja (npr. briga za dijete $\mathrm{u}$ istraživanju Bajer i Kljaić, 1990.). Vjerojatno tome pridonosi i dob sudionika u ovom istraživanju (kasna adolescencija). Istraživanja koja upućuju na važnost doprinosa roditelja (npr. Snyder i Stoolmiller, 2004.) govore o značenju roditeljskih ponašanja tijekom djetinjstva i rane adolescencije. Drugi mogući razlog neznačajnosti roditeljskih varijabli jest percepcija roditeljskoga ponašanja: moguće je da su mladići s nepovoljnijim roditeljskim ponašanjem to uljepšavali ili smatrali uobičajenim ponašanjem roditelja, na što upućuje i Ajduković (2001.). U prilog tomu govore i podaci Ricijaša (2009.), koji je utvrdio da više od 75\% mladih kojima su, zbog kršenja zakona, izrečene sankcije procjenjuje svoje obiteljske prilike vrlo povoljnima te iskazuje kako su zadovoljni svojim obiteljskim prilikama. Stoga je, osim doživljaja roditeljskoga ponašanja, potrebna i objektivna procjena roditeljskoga ponašanja.

Analize varijance pokazuju da se skupine značajno razlikuju po sljedećim činiteljima rizika: po oba činitelja rizika vezana uz vršnjake, negativnom roditeljstvu obaju roditelja i 
DRUŠ. ISTRAŽ. ZAGREB GOD. 21 (2012), BR. 2 (116)

STR. $421-441$

ŠINCEK, D.

AJDUKOVIĆ, M.: RAZLIKE MEĐU. popustljivosti majke te po sljedećim problemima ponašanja i doživljavanja: anksioznosti/depresiji, problemima mišljenja, problemima pozornosti, samodestruktivnosti i somatskim problemima, kao i po dva činitelja svrstana u sociodemografske činitelje (broj ponavljanih razreda i mjere izrečene braći i sestrama). Post-hoc analize (Scheffeov test) pokazale su da se sve tri skupine razlikuju jedino na varijablama vezanima uz vršnjake, dok se na većini ostalih činitelja rizika dvije skupine sa srednjom i visokom razinom društveno neprihvatljiva ponašanja razlikuju od skupine niske razine takva ponašanja, ali ne i međusobno.

Prema postavkama Terrie Moffitt, očekivali bismo da će se mladi s ranim i mladi s kasnim javljanjem društveno neprihvatljiva ponašanja međusobno razlikovati po problemima ponašanja i doživljavanja (npr. da će mladi s ranim javljanjem društveno neprihvatljiva ponašanja imati izraženije probleme pozornosti). Prema istraživanjima iz Oregonske studije mladih (Patterson i Yoerger, 2004.), ali i istraživanju provedenom u našoj zemlji (Bajer i Kljaić, 1990.), očekivali bismo da će mladi s ranim javljanjem društveno neprihvatljiva ponašanja imati izraženija negativna obilježja roditeljskoga ponašanja nego druge dvije skupine. Podsjećamo na to da su i mladi srednje i visoke razine društveno neprihvatljiva ponašanja u našem istraživanju manje rizični od mladih ekstremne razine društveno neprihvatljiva ponašanja, kakvi su praćeni u ovim istraživanjima. U tom kontekstu treba razmotriti i slabu točnost klasifikacije mladih s kasnim javljanjem društveno neprihvatljiva ponašanja - ti mladi su "granična" skupina između mladih niske razine društveno neprihvatljiva ponašanja i mladih s kasnim javljanjem društveno neprihvatljiva ponašanja. Također, važno je provoditi dodatna istraživanja kako bi se što točnije utvrdili činitelji rizika specifični za ovu skupinu mladih (koji omogućuju i bolje razlikovanje mladih s kasnim javljanjem društveno neprihvatljiva ponašanja od ostale dvije skupine).

Može se zaključiti da se mladi s kasnim javljanjem društveno neprihvatljiva ponašanja ne razlikuju od mladih s ranim javljanjem društveno neprihvatljiva ponašanja - ipak, razlikovanje po činiteljima rizika, pa i razlikovanje po izraženosti različitih oblika društveno neprihvatljiva ponašanja, govori suprotno. Ono što se iz ovih podataka vidi jest da su razlike, koje su statistički značajne, male. Smatramo da su potrebna dodatna istraživanja kako bismo donijeli konačnu odluku o tome hoćemo li zanemariti te razlike i kojoj ćemo skupini "pribrojiti" ove mlade - skupini niske razine društveno neprihvatljiva ponašanja (jer se od te skupine ne razlikuju po skali Upitnika SRDP-2005 Teže krađe, provale i razbojništva i po nekim činiteljima rizika) ili skupini s ranim javljanjem društveno neprihvatljiva ponašanja (jer se od te skupine ne 
razlikuju po drugim činiteljima rizika). Za sada smatramo da je ovo još jedan pokazatelj u prilog ideji društveno neprihvatljiva ponašanja kao kontinuuma, imajući na umu što ideja kontinuuma znači (blagi "prijelazi" koji dovode do sličnosti skupina, ali i određene specifičnosti svake skupine).

Achenbach, T. M. (1991.), Manual for the Youth Self-Report and 1991 Profile, Burlington, VT, University of Vermont Department of Psychiatry.

Ajduković, M. (2001.), Utjecaj zlostavljanja i zanemarivanja u obitelji na psihosocijalni razvoj djece. Dijete $i$ društvo, 3 (1-2): 59-75.

Bajer, M. i Kljaić, S. (1990.), Kasniji životni put delinkventne djece, Zagreb, Radna zajednica Republičke konferencije Saveza socijalističke omladine Hrvatske.

Dishion, T. J., Capaldi, D. M. i Yoerger, K. (1999.a), Middle Childhood Antecedents to Progressions in Male Adolescents Substance Use: An Ecological Analysis of Risk and Protection. Journal of Adolescent Research, 14 (2): 175-205. doi:10.1177/0743558499142003

Dishion, T. J., Eddy, J. M., Haas, E., Li, F. i Spracklen, K. (1997.), Friendship and Violent Behavior during Adolescence. Social Development, 6 (2): 207-223. doi:10.1111/j.1467-9507.1997.tb00102.x

Dishion, T. J., McCord, J. i Poulin, F. (1999.b), When Interventions Harm: Peer Groups and Problem Behaviour. American Psychologist, 54 (9): 755-764. doi:10.1037//0003-066X.54.9.755

Dishion, T. J. i Owen, L. D. (2002.), A Longitudinal Analysis of Friendship and Substance Use: Bidirectional Influence from Adolescence to Adulthood. Developmental Psychology, 38 (4): 480-491. doi:10.1037//00121649.38.4.480

Dishion, T. J. i Patterson G. R. (1999.), Model Building in Developmental Psychopathology: A Pragmatic Approach to Understanding and Intervention. Journal of Clinical Child Psychology, 28 (4): 502-512. doi:10.1207/S15374424JCCP2804_10

Dishion, T. J. i Patterson, G. R. (2006.), The Development and Ecology of Antisocial Behavior. U: D. Cicchetti i D. Cohen (ur.), Developmental Psychopathology. Vol. 3. Risk, Disorder and Adaptation (Revised ed.), (str. 503-541), New York, Wiley \& Sons.

Dishion, T. J., Patterson G. R. i Kavanagh, K. A. (1992.), An Experimental Test of the Coercion Model: Linking Theory, Measurement, and Intervention. U: J. McCord i R. E. Tremblay (ur.), Preventing Antisocial Behavior (str. 253-282), New York, The Guilford Press.

Dishion, T. J., Poulin, F. i Burraston, B. (2001.), Peer Group Dynamics Associated with Iatrogenic Effects in Group Interventions with High-Risk Young Adolescents. U: C. Erdley i D. W. Nangle (ur.), Damon's New Directions in Child Development: The Role of Friendship in Psychological Adjustment (str. 79-92), San Francisco, Jossey-Bass.

Farrington, D. P. (2003.), Developmental and Life-Course Criminology: Key Theoretical and Empirical Issues - The 2002 Sutherland Award Address. Criminology, 41 (2): 221-255. doi:10.1111/j.1745-9125. 2003.tb00987.x 
DRUŠ. ISTRAŽ. ZAGREB GOD. 21 (2012), BR. 2 (116) STR. $421-441$

ŠINCEK, D. AJDUKOVIĆ, M.: RAZLIKE MEĐU..
Koller-Trbović, N. (2004.), Poremećaji u ponašanju djece i mladih. U: J. Bašić, N. Koller-Trbović i S. Uzelac (ur.), Poremećaji u ponašanju: pristupi i pojmovna određenja (str. 83-96), Zagreb, Edukacijsko - rehabilitacijski fakultet.

Kuterovac Jagodić, G., Keresteš, G. i Brković, I. (2007.), Attachment Styles of Parents of Adolescents and their Parenting Behavior. U: Ćubela Adorić, V. (ur.), 15th Psychology Days in Zadar: Book of Selected Proceedings (str. 167-183), Zadar, University of Zadar.

Loeber, R. i Stouthamer-Loeber, M. (1986.), Family Factors as Correlates and Predictors of Juvenile Conduct Problems and Delinquency. Crime and Justice. An Annual Review of Research, 7: 29-149. doi:10. 1086/449112

Moffitt, T. E. (1990.), Juvenile Delinquency and Attention Deficit Disorder: Boys' Developmental Trajectories from Age 3 to Age 15. Child Development, 61 (3): 893-910. doi:10.2307/1130972

Moffitt, T. E. (1993.), Adolescence-Limited and Life-Course-Persistent Antisocial Behavior: A Developmental Taxonomy. Psychological Review, 100 (4): 674-701. doi:10.1037//0033-295X.100.4.674

Moffitt, T. E., Caspi, A., Rutter, M. i Silva, P. A. (2001.), Sex Differences in Antisocial Behavior: Conduct Disorder, Delinquency, and Violence in the Dunedin Longitudinal Study, Cambridge, Cambridge University Press.

Paterrson, G. R. (1998.), Coercion as a Basis for Early Age of Onset for Arrest. U: J. McCord (ur.), Coercion and Punishment in Long - Term Perspectives (str. 81-105), Cambridge, Cambridge University Press.

Patterson, G. R. (2004.), The Early Development of Coercive Family Process. U J. B. Reid, G. R. Patterson i J. Snyder (ur.), Antisocial Behavior in Children and Adolescents: A Developmental Analysis and Model for Interventions (str. 25-44), Washington, DC, APA.

Patterson, G. R., Reid, J. B i Dishion, T. J. (1992.), Antisocial Boys, Eugene, Oregon, Oregon Social Learning Center.

Patterson, G. R., Reid, J. B. i Eddy, J. M. (2004.), A Brief History of the Oregon Model. U: J. B. Reid, G. R. Patterson i J. Snyder (ur.), Antisocial Behavior in Children and Adolescents: A Developmental Analysis and Model for Interventions (str. 3-21), Washington, DC, APA.

Patterson, G. R. i Stouthamer-Loeber, M. (1984.), The Correlation of Family Management Practices and Delinquency. Child Development, 55 (4): 1299-1307. doi:10.2307/1129999

Patterson, G. R., Shaw, D. S., Snyder, J. J. i Yoerger, K. (2005.), Changes in Maternal Ratings of Children Overt and Covert Antisocial Behavior. Aggressive Behavior, 31 (5): 473-484. doi:10.1002/ab.20095

Patterson, G. i Yoerger, K. (2004.), A Developmental Model for Earlyand Late-Onset Delinquency. U: J. B. Reid, G. R. Patterson i J. Snyder (ur.), Antisocial Behavior in Children and Adolescents: A Developmental Analysis and Model for Interventions (str. 147-172), Washington, DC, APA.

Reid, J. B., Patterson, G. i Snyder, J. (2004.), Antisocial Behavior in Children and Adolescents: A Developmental Analysis and Model for Interventions, Washington, DC, APA.

Ricijaš, N. (2009.), Pripisivanje uzročnosti vlastitog delinkventnog ponašanja mladih, Zagreb, Pravni fakultet, neobjavljena doktorska disertacija. 
DRUŠ. ISTRAŽ. ZAGREB GOD. 21 (2012) BR. 2 (116),

STR. $421-441$

ŠINCEK, D

AJDUKÓVIĆ, M.

RAZLIKE MEĐU.
Ručević, S., Ajduković, M. i Šincek, D. (2009.), Razvoj Upitnika samoiskaza rizičnog i delinkventnog ponašanja mladih (SRDP-2007). Kriminologija i socijalna integracija, 17 (1): 1-11.

Rutter, M., Giller, H. i Hagell, A. (1998.), Antisocial Behavior by Young People, Cambridge, Cambridge University Press.

Snyder, J. (2004.), Reinforcement and Coercion Mechanisms in the Development of Antisocial Behavior: Peer Relationship. U: J. B. Reid, G. R. Patterson i J. Snyder (ur.), Antisocial Behavior in Children and Adolescents: A Developmental Analysis and Model for Interventions (str. 101-122), Washington, DC, APA.

Snyder, J. i Patterson, G. (1987.), Family Interaction and Delinquent Behavior. U: H. C. Quay (ur.), Handbook of Juvenile Delinquency (str. 216-243), New York, John Wiley \& Sons.

Snyder, J. i Stoolmiller, M. (2004.), Reinforcement and Coercion Mechanisms in the Development of Antisocial Behavior: The Family. U: J. B. Reid, G. R. Patterson i J. Snyder (ur.), Antisocial Behavior in Children and Adolescents: A Developmental Analysis and Model for Interventions (str. 65-100), Washington, DC, APA.

Stouthamer-Loeber, M., Loeber, R., Wei, E., Farrington, D. P. i Wikstrom, P. (2002.), Risk and Promotive Effects in the Explanation of Persistent Serious Delinquency in Boys. Journal of Consulting Clinical Psychology, 70 (1): 111-123. doi:10.1037//0022-006X.70.1.111

Thornberry, T. P. (1987.), Toward an Interactional Theory of Delinquency. Criminology, 25 (4): 863-892. doi:10.1111/j.1745-9125.1987.tb 00823.x

\section{Differences among Male Adolescents with Early- and Late-Onset of Risk Behavior}

\author{
Daniela ŠINCEK \\ Faculty of Philosophy, Osijek \\ Marina AJDUKOVIĆ \\ Faculty of Law, Zagreb
}

Taxonomies of socially unacceptable behavior differentiate youth with late- and early-onset. Youth with early onset are considered riskier. Research showed that parents behavior is more important for onset, and peers for continuation of risk behavior in the early-onset group. Peers are more important for the late-onset group. The present research investigated differences in the intensity of socially unacceptable behavior and risk factors among early-onset and late-onset adolescents, and in the intensity of different risk factors (e.g. siblings riskiness, behavioral and emotional problems, parental behavior and peer factors). Participants were 661 male adolescents from Osijek and Zagreb. They were in three groups: group with low level of socially unacceptable 
DRUŠ. ISTRAŽ. ZAGREB GOD. 21 (2012), BR. 2 (116)

STR. $421-44$

ŠINCEK, D.

AJDUKOVIĆ, M.:

RAZLIKE MEĐU.. behavior ( $N=227)$, group with late-onset $(N=231)$, and group with early-onset ( $N=203$ ). Results suggest that groups with early- and late-onset differ in the intensity of their socially unacceptable behavior. Three groups differ in characteristics of their peer group (early-starters have the riskiest peers and are most influenced by peers), but they don't differ in the intensity of other risk factors.

Keywords: socially unacceptable behavior, adolescents, early and late starters 